\title{
The Melville Bay area, North-West Greenland - the first phase of petroleum exploration
}

\author{
Richard C. Whittaker and \\ Niels Erik Hamann
}

The lirst detailed interpretation of the structure and geological development of the Melville Bay area based on reflection seismic data was completed in June 1994 as part of the KANUMAS project (Larsen \& Pulvertaft, 199()). This marks the first step in the exploration for petroleum offshore North-West Greenland and has resulted in renewed optimism for the oil potential of the region.

\section{Background}

The Melville Bay (Melville Bugt) areal lies in the northcast comer of Baffin Bay (Baffin Bugt), covering the continental shelf between Svartenhuk Halvos and Carcy Øer
(Fig. 1). This vast frontier exploration area, which extends for about $8(0) \mathrm{km}$ from north-west to south-east and has a maximum width of about 240 $\mathrm{km}$, is approximately equivalent in size to the Central and Viking (irabens of the North Sea put together. Most of the continental sheff in Melville Bay is in moderate to deep water. generally between $2(0) \mathrm{m}$ and $5(0) \mathrm{m}$. Physical conditions in the areat are harsh. The area is covered by sea-ice from October to July and scattered large icehergs are present all year round.

The first indication that a major sedimentary basin existed in the area came from the interpretation of a regional airborne magnetic survey covering Balfin Bay (Hood ef (1.. 1967). In 197() the Bedford Institute of Oceanography

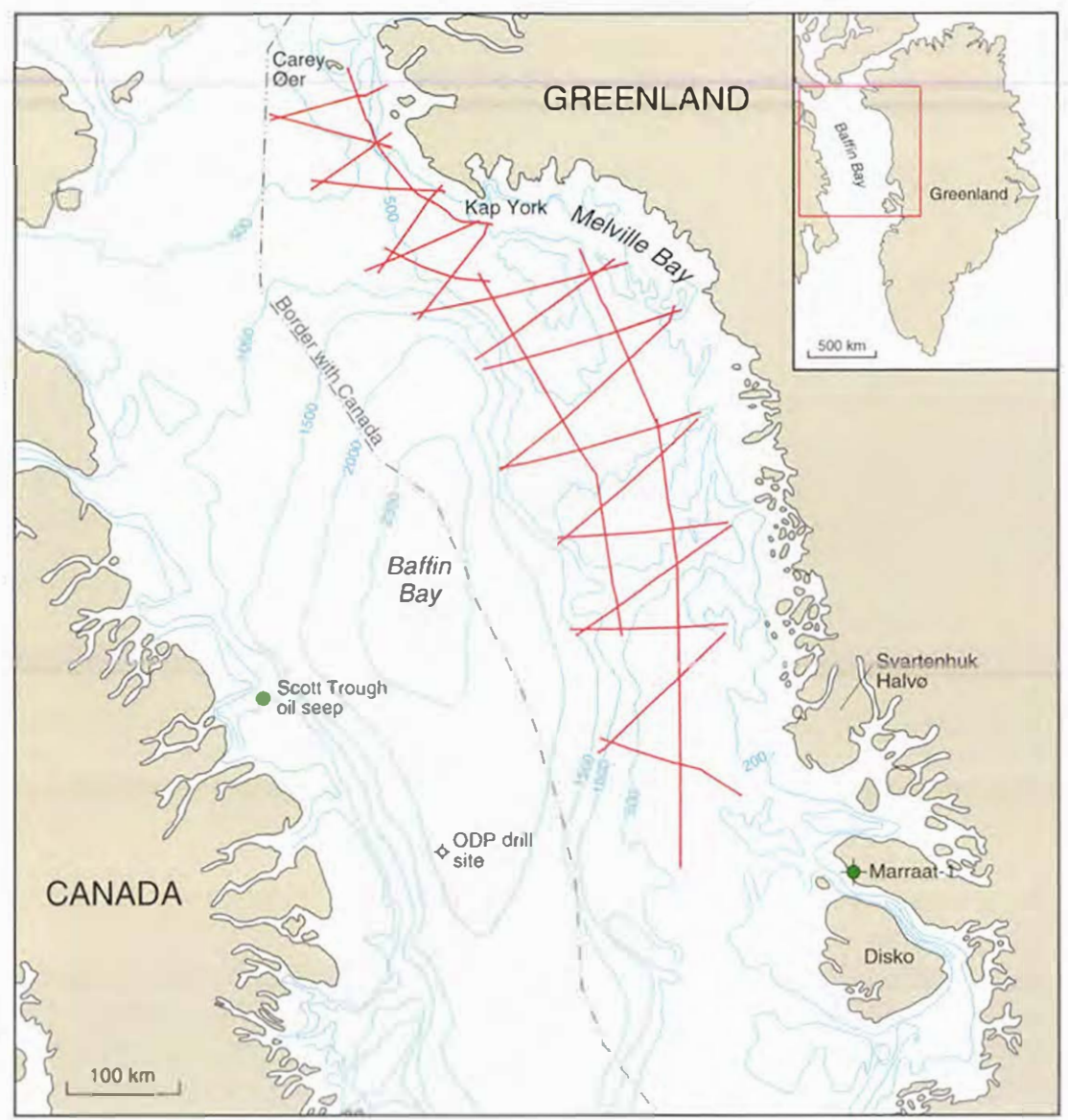

Fig. I. Loxation map of the Melville Bay areal showing the KANUMAS seismic survey. Water depths (in metres) are also shown. along with the position of the Marratat- I well and the Scoutrough oil seep. 

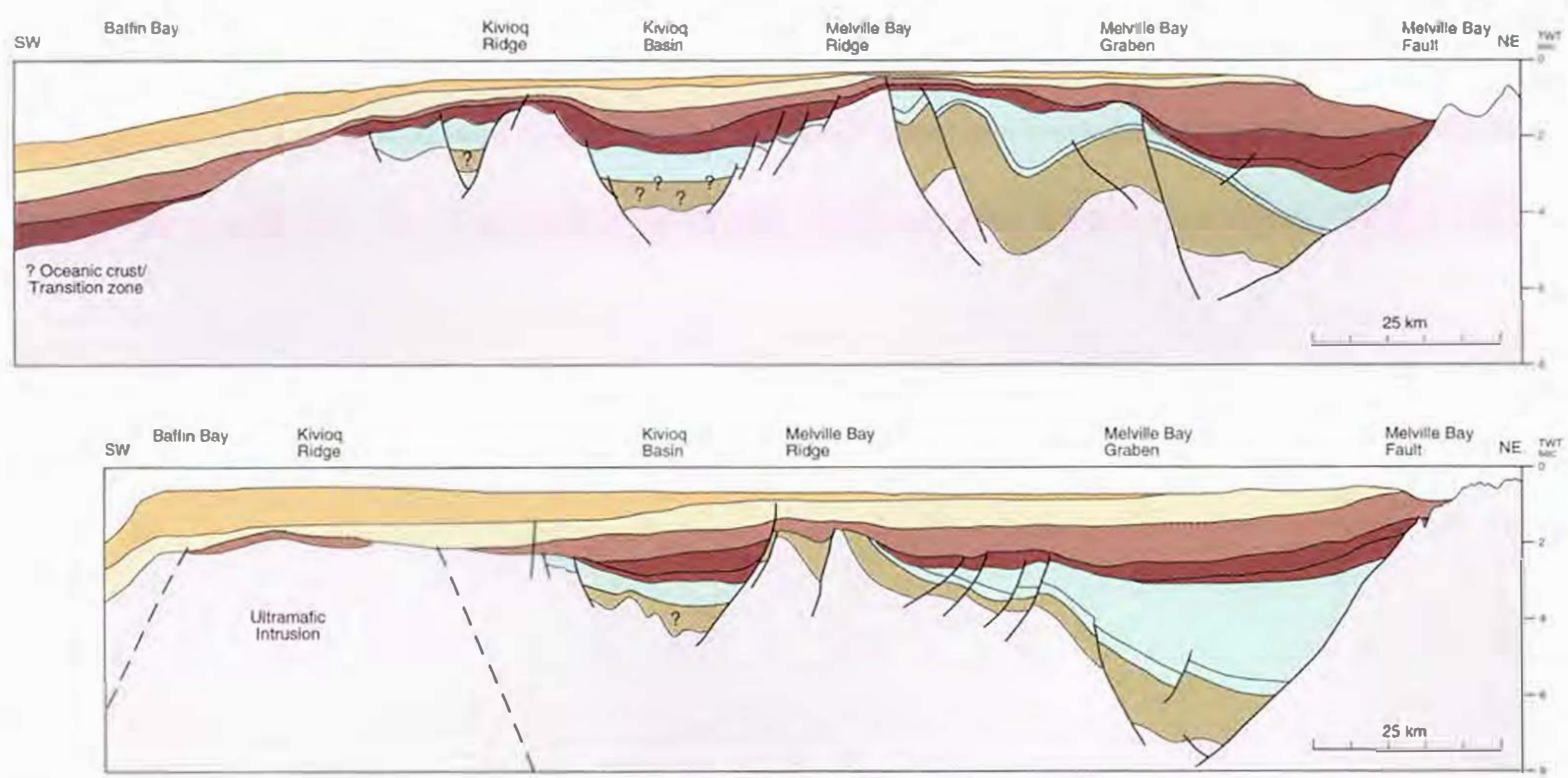

Fig. 2. Representative structural cross-sections of the Melville Bay area.

and Dalhousic University (Halifax. Nova Scotia) began a comprehensive geophysical study of Baftin Bay which provided further evidence for the presence of a major basin or graben in this area. A map based largely on gravity data accuured during this study showed the extent of the graben and revealed the thickness of the sedimentary till to reach $10 \mathrm{~km}$ (Ross \& Henderson, 1973).

It was not until 1992 that the lirst systematic seismic reflection survey was carried out in Melville Bay. The seismic reconnaissance survey formed part of the KANUMAS project, which is a regional seismic project covering (wo major unexplored shelf areas: Melville Bay and the North-East Greenland shelf. The KANUMAS project is funded by a group of oil companies consisting of $\mathrm{BP}$, Exxon, Japan National Oil Company. Nunaoil, Shell, Statoil and Texaco, with Nunaoil A/S (the national oil compatny of Greenland) as operator.

\section{Data acquisition and processing}

In the period 20 August to 17 September 1992 Nunaoil acquired $4(1) 7 \mathrm{~km}$ of seismic reflection data along 23 lines (Fig. 1), using the Danish Navy high ice-class fisheries inspection ship Thetis, which has been adapted to carry scismic equipment. Despite the harsh conditions few problems were encountered, and there was very little downtime'. mainly because seal conditions were predominantly calm in the area. The data were processed by Halliburton Geophysical Services Inc.. England under the supervision of Nunaoil.

Gravity profiles acquired together with the seismic lines were processed by the Danish National Survey and Cadastre (KMS) and were supplemented by additional marine gravity data and airborne gravity data (supplied by John Brozena of the U. S. Naval Research Laboratory. 19911992), and with satellite altimetry data, 10 produce a composite Bouguer anomaly map. The composite gravity map reveals trends and features not discernable from the widely spaced seismic lines.

All KANUMAS data. both seismic lines and gravity data, are the property of the partners in the project and are confidential.

\section{Basin evaluation}

Interpretation of the seismic data was carried out in close cooperation with Nunaoil on behall of the KANUMAS group of companies, for whom GGU acted as geological and geophysical consultants on the project. The interpretation work was performed primarily on Landmark interactive work stations at GGU and Nunaoil. A full interpretation report covering the structure, basin development and petroleum potential of the area was submitted 10 the KANUMAS partners in June 1994, and a copy of this report was deposited with the Mincral Resources Administration for Greenland (MRA).

An impression of the main geological features of the Melville Bay area can be gained from two representative cross-sections drawn from seismic lines (Fig. 2). The seismic sections confirm the existence of deep sedimentary basins in the areat and indicate the presence of potentially large structural traps for hydrocarbons. A series of struc- 


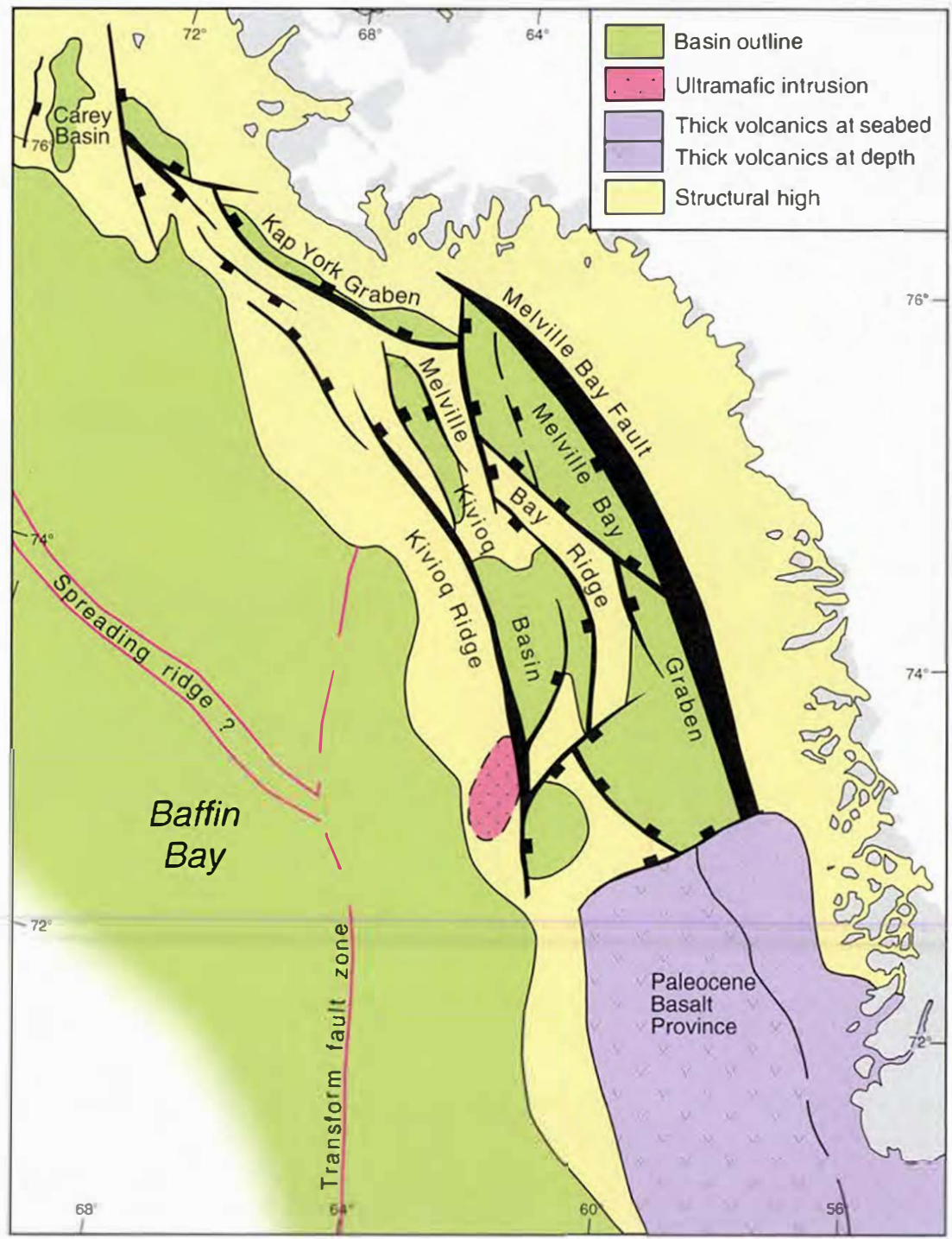

Fig. 3. Tectonic elements map of the Melville Bay area. ture contour maps, produced from the interpretation, are summarised in the structural elements map of the Melville Bay area (Fig. 3) which has been incorporated in the new 1:2 50() ()() Geological map of Greenland (Escher \& Pulvertaft, 1995). This map outlines the major sedimentary basins and shows the extent of Paleocene basalts which continue offishore from outcrops in the Disko-NuussuaqSvartenhuk Halvg area.

The age of the sediments filling the Melville Bay basins is unknown. but the structural and stratigraphic interpretations of the seismic data have been used, together with information from outcrops from around Baffin Bay, to construct a model for the geological development of the area. The geology of Baffin Bay and its surroundings are reviewed in detail by Balkwill el al. (1990) who concluded that the area is a promising hydrocarbon province but that it is likely to be gas-prone. Recent work, however, suggests that oil-prone source rocks could exist at two levels within the Cretaceous and Lower Tertiary section. CenomanianTuronian oil-prone source rocks occur in the Kanguk Formation of the Sverdrup Basin in Arctic Canada (Núñe\%Betelu et al., 1993). This formation was deposited during the marine transgression that extended outside the basin. possibly reaching the Melville Bay area. The likelihood of the presence of a mid-Cretaceous source rock is supported by the occurrence of a submarine oil seep in the Scott Trough on the westem side of Batfin Bay (Fig. 1), which is reported to have come from a Cretaceous source rock (Balkwill et al. 199()). The recent discovery of oil-shows in the Marraat-I well on the Nuussuay peninsula (Fig. 1), and extensive oil seeps in the area around Marrat, suggest that a second oil-prone source interval of Palcocene age is present in the area (Christiansen et al. 1994). 


\section{Outlook}

The structural interpretation of the Melville Bay seismic data, together with recent work pointing to the presence of regionally extensive oil-prone source rocks, has significantly upgraded the oil potential of the region. The report detailing the interpretation of the initial seismic reconnaissance survey of the area is to be used as the basis for the Greenland-Danish authorities' policy regarding future licensing in the Melville Bay area.

\section{References}

Balkwill, H. R., McMillan, N. J., MacLean, B, Williams, G. L. \& Srivastava, S. P. 1990: Geology of the Labrador Shelf, Baffin Bay, and Davis Strait. In Keen, M. J. \& Williams, G. L. (ed.) Geology of the continental margin of eastern Canada, 293-348. Geology of North America I-1 (also Geology of Canada 2, Geological Survey of Canada). Boulder, Colorado: Geological Society of America.

Christiansen, F. G., Bojesen-Koefoed, J. \& Nytoft, P. H. 1994: Organic geochemistry of oil-impregnated cores from the Mar- raat-1 well, Nuussuaq, West Greenland - comparison with surface samples. Open File Ser. Grønlands geol. Unders. 94/8, $32 \mathrm{pp}$.

Escher, J. C. \& Pulvertaft, T. C. R. 1995: Geological map of Greenland 1: 2500 000. Copenhagen: Geological Survey of Greenland.

Hood, P. J., Sawatsky, P. \& Bower, M. E. 1967: Aeromagnetic investigations of Baffin Bay, the North Atlantic Ocean, and the Ottawa area. Pap. Geol. Surv. Canada 68-1, 79-84.

Larsen, H. C. \& Pulvertaft, T. C. R. 1990: Regional marine seismic reconnaissance. Rapp. Grønlands geol. Unders. 148, 3234.

Núñez-Betelu, L. K., Riediger, C. L. \& Hills, L. V. 1993: RockEval analysis of the Cretaceous Bastion Ridge and Kanguk Formations, Axel Heiberg and Ellesmere islands, Canadian arctic archipelago. Annual Meeting Geological Association of Canada 1993, Program with Abstracts, A-78.

Ross, D. I. \& Henderson, G. 1973: New geophysical data on the continental shelf of central and northem West Greenland. Can. J. Earth Sci. 10, 485-497.

R. C. W., Geological Survey of Denmark and Greenland, Copenhagen

N. E. H., Nunaoil A/S, Pilestrade 40C, DK-1112 Copenhagen K 